\title{
THE STREETS OF ROME AS A REPRESENTATION \\ OF IMPERIAL POWER ${ }^{1}$
}

By

\author{
ANDREW WALLACE-HADRILL
}

\begin{abstract}
"In vain, great hearted Kublai, shall I attempt to describe Zaira, city of high bastions. I could tell you how many steps make up the streets rising like stairways, and the degrees of the arcades' curves, and what kind of zinc scales cover the roofs; but I already know this would be the same as telling you nothing." (Italo Calvino) $^{2}$
\end{abstract}

Rome was a microcosm of Roman imperial power, the showplace of imperial might. The image of the emperor was written in his city. We all know this. But what shall I do? Shall I enumerate for you the statistics of Rome's magnificence, as does the elder Pliny, or as do the Regionary Catalogues? If I did so, this would, as Italo Calvino suggests, be the same as telling you nothing. We can follow the elder Pliny in enumerating the statistics of Rome's magnificence, counting the regions and crossroads shrines, the length of the walls, the length of the streets leading to the gates.

"The circuit of the walls of Rome in the censorship of the emperors Vespasian was 170 miles, including 7 hills. It is divided into 14 regions, and 265 shrines of the Lares. If a straight line is drawn from the milestone standing at the head of the Roman Forum to each of the gates, which today number 37 (provided that the Twelve Gates be counted only as one each and the seven of the old gates that no longer exist be omitted), the result is a total of 20 miles 765 yards in a straight line... If you add to all that the height of the houses, you may form a proper

\footnotetext{
${ }^{1}$ This paper was delivered in an earlier version at the conference at the Netherlands Institute at Rome, and in a later version at Princeton University. I am grateful to participants on both occasions for valuable comments, and especially to Ray Laurence for sharing thoughts about neighbourhoods, and to Rosie Harman for invaluable help with the final text.

${ }^{2}$ Italo Calvino, Le città invisibili (la città e la memoria 3): 'Inutilmente, magnanime Kublai, tenterò di descrivere la città di Zaira dagli alti bastioni. Potrei dirti di quanti gradini sono le vie fatte a scale, di che sesto gli archi dei porticati, di quali lamine di zinco sono ricoperti i tetti; ma so che sarebbe come non dirti nulla.' I owe the quotation to R. Laurence in P. Carl, B. Kemp et al., 'Were cities built as images?', Cambridge Archaeological Journal 10:2 (2000), 346.
} 
estimate, and admit that no city in all the world can be compared in size." 3

Pliny's statistics exist not to enlarge our understanding, but as a trope of rhetorical hyperbole, much though we welcome the statistic he adds, that Vespasianic Rome had 265 compita (hence, we infer, vici or neighbourhoods). The fourth-century Regionary Catalogues belong to the same tradition of mirabilia: when they tell us not only how many temples, theatres, fora and baths, but how many houses, insulae, horrea, bakeries, reservoirs, not to speak of latrines and brothels, the city could boast, the intention is to stun us with numbers. ${ }^{4}$ Modern scholars continue to play the game, for quite different reasons, assembling figures for the number of inhabitants, the thousands of tonnes of wheat they consumed, the millions of litres of olive oil, the hundreds of thousands of kilos of pork sausages. ${ }^{5}$ The modern concern for statistics colludes with the ancient obsession with mirabilia.

I am not seeking to belittle Rome, but to get a sharper focus on the issue of representation of imperial power. How did Rome represent the emperor, beyond saying he was big? What nature of power, what structure of social and economic relationships, did it symbolically figure? Because my interest has been for some time not so much in public monuments as the anonymous and diverse assemblage of private building (houses, insulae, shops, warehouses, private baths etc), my focus is on how we can read imperial power in the back streets, not just the Colosseum. ${ }^{6}$ In this paper, I pass over these public monuments, on which the discussion of the question is normally focussed.

\footnotetext{
${ }^{3}$ Pliny, Naturalis Historia 3.66-7: Moenia eius collegere ambitu imperatoribus censoribusque Vespasianis anno conditae DCCCXXVI m.p. XXX.CC, conplexa montes septem. ipsa dividitur in regiones quattuordecim, compita Larum CCLXV. eiusdem spatium mensura currente a miliario in capite Romani fori statuto ad singulas portas, quae sunt hodie numero XXXVII ita ut duodecim semel numerentur praetereanturque ex veteribus VII quae esse desierunt, efficit passuum per directum XX.M.DCCLXV.....quod si quis altitudinem tectorum addat, dignam profecto aestimationem concipiat, fateaturque nullius urbis magnitudinem in toto orbe potuisse ei comparari. See plates IV, fig. 1 for the 14 regiones of imperial Rome (added by the editors).

${ }^{4}$ A. Nordh, Libellus de regionibus urbis Romae (Lund 1949). For the rhetoric, see J. Arce, 'El inventario de Roma: Curiosum y Notitia', in W.V. Harris, ed., The Transformations of Urbs Roma in Late Antiquity (Journal of Roman Archaeology suppl 33, 1999), 15-22.

${ }^{5}$ For the value of such statistics to demography, see e.g. E. Lo Cascio, 'Canon frumentarius, suarius, vinarius: stato e privati nell'approvvigionamento dell'Urbs', in Harris 1999, op.cit. (n.4), 163-182.

${ }^{6}$ See my recent contributions, 'Case e abitanti a Roma' in E. Lo Cascio, ed., Roma Imperiale. Una metropoli antica (Roma 2000), 173-220, and 'Emperors and houses in Rome' in S. Dixon, ed., Childhood, Class and Kin in the Roman World (London/ New York 2001), 128-143.
} 
Cities, as a recent Cambridge workshop on 'Were cities built as images?' has emphasised, are the outcome of a tension between ideal and praxis. ${ }^{7}$ We do well to ask, as Joseph Rykwert did in his Idea of the Town with reference to Rome, ${ }^{8}$ or Paul Wheatley in his Pivot of the Four Quarters with reference to ancient China, ${ }^{9}$ what cosmological and other ideals the built town seeks to embody; but we must also hold on to the role of praxis, the everyday necessities and the banalities of routine practice. Those who work on shantytowns are more alive to the imperatives of praxis:

"Beneath the apparent chaos of the modern squatter settlement, there is often a clear consistency of form and urban structure which varies from place to place. Such consistencies derive at the local level from the relationship between urban form and social processes. Local spatial customs and unwritten social codes determine the layout, spacing and growth of houses, and the development of plots and settlement form.",10

Imperial Rome is indeed an ideal city, but only in part. Beyond question it sought to project an image of imperial power, in some quite specific ways at different periods; simultaneously it was the outcome of praxis, remorselessly generating urban form over the centuries. Our job is not to magnify the emperors, but to investigate the nature and limits of their power, and to read the built environment as the outcome of an eternal struggle between the assertion of the ideal of imperial omnipotence, and the massive limitations imposed by the daily realities of this city of a million souls, a monster which the empire created, and then struggled to control.

It may help to start by focusing on what imperial Rome was not. It was not a city of parade routes and broad, straight avenues. It was a twentiethcentury dictator not a Roman emperor who drove the Via dell'Impero as a parade route from Piazza Venezia to the Colosseum. The route of the Roman triumph was circuitous, winding, and at many points surprisingly narrow.

\footnotetext{
${ }^{7}$ Carl, Kemp et al. 2000, op.cit (n.2), 327-365.

${ }^{8} \mathrm{~J}$. Rykwert, The Idea of the Town: the Anthropology of Urban Form in Rome, Italy and the Ancient World (Cambridge Mass. 1976).

${ }^{9}$ P. Wheatley, Pivot of the Four Quarters: a Preliminary Enquiry into the Origins and Character of the Ancient Chinese City (Edinburgh 1971).

${ }^{10}$ B. Erickson \& T. Lloyd-Jones, 'Experiments with settlement aggregation models', Environment and Planning B: Planning and Design 24 (1997), 903-928, cited by Kemp in Carl, Kemp et al. 2000, op.cit. (n.2), 342.
} 
Imperial Rome was not a Renaissance ideal city. ${ }^{11}$ The Renaissance ideal required perspectival vistas with vanishing points: from Pope Julius II's via Giulia, cutting through the medieval mess of the southern Campus Martius towards the Vatican, to Paul III Farnese's 'Tridente', to Sixtus V's long vistas marked by obelisks. ${ }^{12}$ Cutting new streets through the existing urban fabric has been one of the prime ways of inscribing power upon the face of the city. The Renaissance ideal is not universal, but specific to its own set of historical circumstances. It involves the denial and deletion of another, medieval image of the city, of baronial families with their strongholds, like the Orsini in Pompey's theatre, or the Savelli in that of Marcellus. ${ }^{13}$ The characteristic of such a city is the torre as heart of power of the family clan, surrounded by a local maze of narrow streets, the contrada or patch the family controls. Less visible now in Rome, we see it best in Genoa, where the streets of the centre, based on the grid pattern of the Roman colony, are still now a maze in which the cellular structure is clear. ${ }^{14}$ The Renaissance ideal is an attempt to wipe out this power structure, and the city plan is legible as the palimspest of the outcome of power structures.

Imperial Rome too had its debate about ideal street plans. Consider the discussion surrounding the Great Fire of Rome under Nero.

"The rest of the city was not, as after the Gallic fire, put up indiscriminately and all over the place, but districts (vici) were measured and laid out, streets were broad, heights of houses were limited, with wide open spaces, and porticoes added to protect the frontages of insulae."15

\footnotetext{
11 E. Künzl, Der römische Triumph: Siegesfeiern im antikes Rom (Munich 1988), 15, 30-44; F. Coarelli, Il Campo Marzio dalle origini alla fine della repubblica (Rome 1997), 118-135 et passim.

${ }^{12}$ On the military and social considerations underpinning such schemes, see Richard Ingersoll, 'Piazza di Ponte and the Military Origins of Panopticism' in Z. Çelik, D. Favro \& R. Ingersoll, eds, Streets: Critical Perspectives on Public Space (Berkeley 1994), 177-188 and C. Burroughs, 'Absolutism and the Rhetoric of Topography' ibid. 189-202.

${ }^{13}$ See R. Brentano, Rome before Avignon: a Social History of Thirteenth-century Rome (London 1991); J.-C. Mairie-Vigueur, ed., D'une ville a l'autre: structures matérielles et organisation de l'espace dans les villes européennes (XIII-XVI siècles). Collection de l' École Française de Rome 122 (Rome 1989).

${ }^{14}$ See L. Grossi Bianchi and E. Poleggi, Una città portuale del medioevo: Genova nei secoli X-XVI (Genoa 1980); Wallace-Hadrill 2001, op.cit. (n. 6), 130f.

is Tacitus Annals 15.43: ceterum urbis quae domui supererant non, ut post Gallica incendia, nulla distinctione nec passim erecta, sed dimensis vicorum ordinibus et latis viarum spatiis cohibitaque aedificiorum altitudine ac patefactis areis additisque porticibus, quae frontem insularum protegerent.
} 
Tacitus' negative reference to the rebuilding of Rome after the Gallic sack deliberately evokes the Livian commentary on that event, which laments the missed opportunity to set out Rome as a decently ordered city, rather than a squatter settlement. ${ }^{16}$ It was of course a continuing paradox that Roman colonies presented the image of the ideal city with an ordered grid pattern for centuries, while Rome did not. ${ }^{17}$ Why not? The real reasons are to do above all with the topography of the landscape (the road system follows the contours of the seven hills), and with the historic evolution of the settlement perpetuated through individual property rights. Ironically, Livy's reference to the neglect of property rights after the Gallic sack puts the finger on what gave Rome its disordered appearance. It is surely that the sack did not disrupt property rights, and Rome continued to follow its old pattern. ${ }^{18}$ Only when the central authority of a city can arrogate to itself the power to expropriate can broad avenues be cut through existing fabric.

Nero's fire was evidently seen by Romans, including the emperor himself, as a renewed opportunity to impose ideal order on the apparent chaos of praxis. It had some success; but what I want to stress are the limits of that success. There were indeed areas, particularly the port area beneath the Aventine, and in Trastevere, where blocks of houses were laid out in a regular grid, though to be honest we have no knowledge that these resulted from the Neronian regulations or replaced previously chaotic areas. But Rome the squatter settlement continued to flourish, alongside the signs of imperial order. It is enough to consider the area around the Porticus of Livia, of which the fragments of the Forma Urbis happen to survive particularly well. The Porticus itself, which supposedly replaced the over-luxurious house of Vedius Pollio, is indeed a symbol of imperial order, just as much as the surrounding streets are not. The interruption of old street lines by the portico shows clearly the historical nature of the evolution: the rectangle cuts abruptly the older, topographically contoured lines. But it also shows the exception: Vedius' moral opprobrium, coupled with imperial inheritance, permitted an intervention in the urban fabric that was exceptional, not normative. ${ }^{19}$

\footnotetext{
${ }^{16}$ Livy 5.55: festinatio curam exemit vicos dirigendi, dum omisso sui alienique discrimine in vacuo aedificant. ea est causa ut veteres cloacae, primo per publicum ductae, nunc privata passim subeant tecta, formaque urbis sit occupatae magis quam divisae similis.

${ }^{17}$ P. Zanker, The Power of Images in the Age of Augustus (Ann Arbor 1988), $18 \mathrm{ff}$.

${ }^{18}$ R.M. Ogilvie, A Commentary on Livy Books 1-5 (Oxford 1965), 750 f.

${ }^{19}$ Zanker 1988, op.cit. (n.17), 137-139.
} 
It is instructive to compare the situation after the great fire in London of 1666. Christopher Wren and Robert Hooke both submitted designs for a new, modern layout for the City of London, both inspired by visions of how an ideal city should be with its vistas and modular units. But the medieval pattern prevailed, and has survived to the present, thanks above all to property rights. ${ }^{20}$ In the case of Rome too, one may think of it as an ongoing tension between the centralised and idealising power of the state and the individual property rights that gave historical boundaries their tenacious survival. Call this, if you want, the limit of imperial power, and reflect that in some ways both Renaissance popes and the modern nation state has had greater powers of expropriation than the Caesars.

But from another perspective, the powers of the emperors (as they occasionally proclaimed) were limitless. They could have invoked the common welfare, salus rei publicae, to justify radical re-planning of the entire street plan of their imperial showpiece capital. They ostentatiously did not. We may think again of Suetonius' anecdote of Augustus narrowing the plan of his Forum rather than expropriate neighbouring houses: true or not, the biographer assumed that civilitas could be inscribed on the city plan. ${ }^{21}$ That means we are not looking at the limits of imperial power, but its selfdefinition and self-representation: the quality that long ago struck me as distinctive in imperial ideology. ${ }^{22}$ The imperial power that represents itself as continuing, not breaking, the republican past, of championing the rights of the Roman citizen, of upholding the rule of law and of property rights, projects itself in the urban plan in that very juxtaposition of historical fabric modified, not replaced, by new order.

As I argued then, rather than the traditional 'weak' reading of civilitas as the historical compromise that Augustus makes to disguise the transition from the Republic, we can prefer a 'strong' reading. Augustus uses the structures of the city-state to generate his own power. The status hierarchy of citizenship becomes a potent instrument in his hands. At another level, the empire depends more on quasi-independent city-states for its peaceful running than on an army of imperial administrators. ${ }^{23}$ The idea I would like to explore now is that the street plan of imperial Rome is the

\footnotetext{
${ }^{20} \mathrm{Kemp}$ in Carl, Kemp et al. 2000, op.cit. (n.2), 337.

${ }^{21}$ Suetonius Aug. 56.2, forum angustius fecit non ausus extorquere possessoribus proximas domos. Cf. Zanker 1988, op.cit (n.17), 155-156, rightly underlining the deliberate decision by Augustus to display his respect for property.

22 'Civilis Princeps: Between Citizen and King', Journal of Roman Studies 72 (1982), 32-48.

${ }^{23}$ So P. Garnsey \& R. Saller, The Roman Empire. Economy, Society and Culture (London 1987), $26 \mathrm{ff}$.
} 
outcome of an urban order, which depends not simply on central imperial control, but on a cellular structure that operated at local level, and on the deliberate exploitation of that fact by the emperor. In this picture, the city with its vici is a microcosm of the empire with its city-states.

For the overall articulation of the imperial city, the fourth-century Regionary Catalogues remain the indispensable starting point. Their prime use has been by those who want to extract the city's vital statistics, above all the total population based on totals for domus and insulae. ${ }^{24}$ For this purpose I regard them as thoroughly unreliable, though I agree with Filippo Coarelli that it is highly likely that they ultimately reflect the official statistics gathered by the office of the praefectus urbi, stationed surely in the Forum Pacis where the Severan marble plan of Rome was found. ${ }^{25}$ But though individual numbers may be challenged, they surely give us an important insight into the nature of the urban fabric. What I want to underline is what I call the cellular structure. Divided into regiones, and subdivided into vici (by now 320 of them, but the number is dubious), we find in each zone a distribution (unequal, but the numbers are never trustworthy) of the same sort of features: public buildings, temples, baths etc; vici with their vicomagistri (by now exactly 48 per region, which if true means the Augustan system had been changed); private housing (domus and insulae); and all other vital civic amenities, warehouses (horrea), water distribution (lacus), food supply (bakeries), not to speak of urinals and brothels. ${ }^{26}$

To me, that rules out the characteristic of the post-industrial western capitalist city, which is residential differentiation and zoning of activities. As David Harvey has argued, the specific class relations generated by modern capitalism underpin the differentiation of the modern city. ${ }^{27}$ One should not expect, or look for, comparable patterns in antiquity. Modern scholars who have sought to show that Rome was differentiated into districts of the rich and the poor are unconsciously led by the expectations of the modern world. Without denying some differentiation (Testaccio with its warehouses was not like the centre with its fora, let alone the Palatine with its Palace), we are not looking at the sort of zoning of a capitalist city. To understand better how the

\footnotetext{
${ }^{24}$ G. Hermansen, 'The population of imperial Rome', Historia 27 (1978), 129-168; F. Coarelli, 'La consistenza della città nel periodo imperiale: pomerium, vici, insulae', in La Rome impériale: démographie et logistique. Actes de la table ronde (Rome, 25 mars, 1994) (Roma 1997), 89-109.

${ }^{25}$ So F. Coarelli, in Lo Cascio 2000, op.cit. (n.6), 226f.

${ }^{26}$ On vici, A. Fraschetti , Roma e il Principe (Roma/Bari 1990) 204-273 is fundamental, also Zanker 1988, op.cit. (n.17), 129-135; the fullest detail on individual vici is now provided by the Lexicon Topographicum Urbis Romae (LTUR) vol. V (Rome 1999), 151-201, with entries on some 116 vici.

${ }^{27}$ D. Harvey, The Urban Experience (Oxford 1989).
} 
city operates at this micro-level, I want to focus on the vici. The sources tell us the they were the key to the Augustan urban order. The question is how? Here I have four observations to offer.

One critical issue is the extent to which the Augustan vici should be seen as a 'top-down' imposition of an administrative system on the urban fabric, as opposed to a 'bottom-up' manifestation of local solidarity. There is a considerable literature by urban sociologists and geographers on neighbourhood associations, though this is typically focused on the twentieth century western city, with too little consideration of pre-modern and third-world situations. ${ }^{28}$ Even in the modern western city, the neighbourhood is a highly complex phenomenon: too deeply affected by planning and other restraints to be purely 'natural' groups, and too ambivalent and fissiparous to be satisfactorily pinned down by city authorities. ${ }^{29}$ It is striking that even in the squatter towns that are the informal outgrowth of some third-world cities, like Manila, tightly organized neighbourhood groups emerge to play a critical function in helping inhabitants orient themselves in the wider urban environment, carefully policing intruders, and providing mutual support for families knit together by links of patronage. ${ }^{30}$

Whether you look at modern cities or pre-industrial ones, neighbourhood groups represent a whole gamut of possibilities. At one extreme there are the illegitimate groups that terrify the law-enforcement authorities, whether the street gangs of New York, or the control of patches by drug-pushers or prostitution-racketeers, or the more formalised control of Palermo or Naples by competing mafia or camorra families, whose primary concern is to fight each other for the turf. At the other extreme are highly respectable groupings, in particular the parish (a key to urban order in medieval and early modern Europe), or at the most banal level schemes like 'neighbourhood watch' in the UK, organised by the police to get groups of neighbours to defend each other against burglary, encouraged by discounts on insurance premiums. It should not therefore be taken for granted that neighbourhood groupings lead to urban order. Rather the issue is the

\footnotetext{
${ }^{28}$ Thus the classic works of the 'Chicago School', e.g. R. Park, Human Communities: the City and Human Ecologies (Glencoe, Il. 1952).

${ }^{29}$ Particularly valuable is the emphasis of the New Urbanist school on the lived experience of streets: J. Jacobs, Systems of Survival (New York 1992); K. Lynch, Good City Form (Cambridge, Mass. 1991). Their approach is drawn on to excellent effect by J. Hartnett, Streets, Street Architecture, and Social Presentation in Roman Italy (University of Michigan doctoral dissertation 2003).

${ }^{30} \mathrm{M}$. Hollnsteiner-Racelis, 'Becoming an urbanite: the neighbourhood as a learning environment' in:

J. Gugler, ed., The Urbanization of the Third World (Oxford 1988), 230-241.
} 
relationship between the authorities and the wide variety of groupings that arise at grass-roots level.

The ancient sources on Augustus' urban reforms have proved too successful in their tendentious representation of Augustus as reviving a deep Roman tradition. The account in Dionysius of Halicarnassus, attributing to Servius Tullius the entire institution of vici and the celebration in them of the compitalia, should be recognized as a characteristic Augustan 'invention of tradition', the legitimisation of a radical reform by its retrojection on the mythological past. ${ }^{31}$ Hence the unfruitful debate between Mommsen and Waltzing over the degree to which already before Augustus there existed formally structured neighbourhood organisations (collegia) with officials (magistri) and festivals at crossroads (compita). The detailed discussion by Augusto Fraschetti leaves little doubt that though crossroad shrines were indeed a traditional focus of local loyalties, vici were not part of the formal organisation of the republican city, which seems to have preserved to Cicero's day the archaic division into montes and pagi celebrated in the festivals of the Septimontium and Paganalia. ${ }^{32}$

Though the compitalia were part of the official calendar, vici before Augustus seem to have been informal groupings. Certainly, as far as the historical narrative of the late republic is concerned, vici emerge not as part of a formal administrative system, but as a focus for the activities of radical politicians, from Marius Gratidianus, through Catiline's henchman Lentulus, caught by Cicero sending agents around the vici to recruit support for revolution and incendiarism, to the role of Sex Cloelius in running the ludi compitalicii, to Clodius and his recruitment of alleged gangs by some sort of act of formal enrolment vicatim, carried out on the Aurelian tribunal in the forum. ${ }^{33}$ The common thread here is that the vici act as potentially subversive formations which empower the plebs infima, craftsmen and artisans, including people of servile origin, and act as a potential reservoir of alternative power

\footnotetext{
${ }^{31}$ Dionysius Halicarnasseus 4.14.3-4. Fraschetti 1990, op.cit. (n.26), 204-210 argues that the passage precedes the Augustan reform, not to my mind convincingly. For similar retrojection by Dionysius of patronage, cf. A.Wallace-Hadrill, ed., Patronage in Ancient Society (London 1989), 66-68. On the concept of invented tradition, E. Hobsbawm \& T. Ranger, The Invention of Tradition (Cambridge 1983). ${ }^{32}$ Fraschetti 1990, op.cit. (n.26), 123-203, with full references to previous discussion.

${ }^{33}$ On Marius Gratidianus, Cicero, De Officiis 3.80; cf Pliny, Naturalis Historia 34.27; on Catiline, Sallust, Catilina 50; Cicero, In Catilinam 4.17; on Clodius and Sex Cloelius, Cicero, In Pisonem 8 and 23; Asconius ad loc. p.7, 11.9-26 Clark; on Clodius and the Aurelian steps, Cicero, Pro Sestio 34: servorum dilectus habebatur pro tribunali Aurelio nomine collegiorum, cum vicatim homines conscriberentur, decuriarentur.... See Fraschetti 1990, op.cit. (n.26), 210-250.
} 
into which the revolutionary can tap. ${ }^{34}$ The model, in a word, is the street gang not the parish. The skill of Augustus lies in his appropriation of local power networks. In representing his reform as a 'restoration of tradition', he tames a form of power once seen as subversive, and harnesses it to the new system.

That process of harnessing is most visible in the new application of vici to administrative purposes. The first express acknowledgement of their administrative potential is in Caesar's dictatorship, when a census is taken vicatim through owners of domus and insulae; and taken up by Augustus. ${ }^{35}$ Both Caesar and Augustus seem to have been concerned with the lists of entitlement to grain and other benefits, which may provide the clue to Clodius' activities too. A gradual process of acknowledgement of the potential of neighbourhood groups underlies the reform of BC 7, the date supplied by both Cassius Dio's narrative and the majority of dedications by vicomagistri (a couple of exceptions seem to point to the years between 12 and 7). ${ }^{36}$

From now on each vicus has its annual college of 4 magistri and 4 ministri, and acts under authority of the magistrate attributed to the regio. In Dio's narrative the initial context is concern for fire-control, and the firemen for each regio are put under the local authority of the vicomagistri, though this system is shortlived, and the definitive system is regio-based. But it signals the perception that in the emperor's mind the vici form part of an integrated system by which the city is run. What remains undocumented is the connection between the praefectus urbi and his central documentation of the city in the Forum Pacis and the vici as a unit and mechanism for assembling this knowledge. ${ }^{37}$ Nevertheless, it seems to me that what the Regionary Catalogues reflect is an articulated system of knowledge and control in which the vici play a critical role. ${ }^{38}$

But the emphasis on administrative convenience masks the social processes which gave the vici their real power. Zanker has brought out how

\footnotetext{
${ }^{34}$ The importance of the populares for the Augustan reform is stressed by R. Laurence, 'The Urban Vicus: the spatial organisation of power in the Roman city', in E. Herring, R. Whitehouse \& J. Wilkins, eds, Papers of the Fourth Conference of Italian Archaeology I. The Archaeology of Power, Part I (London 1991), 145-152.

${ }^{35}$ Suetonius Iulius 41.3: recensum populi nec more nec loco solito, sed vicatim per dominos insularum egit atque ex viginti trecentisque milibus accipientium frumentum e publico ad centum quinquaginta retraxit; Augustus 40.2 , populi recensum vicatim egit, ac ne plebs frumentationum causa frequentius ab negotiis avocaretur, ter in annum quaternum mensium tesseras dare destinavit; sed desideranti consuetudinem veterem concessit rursus, ut sui cuiusque mensis acciperet.

${ }^{36}$ Dio Cassius 55.8.6-7; Fraschetti 1990, op.cit. (n.26), 250-268 rightly underlines the innovatory power of Augustus' apparent 'restoration of tradition'.

${ }^{37}$ See Coarelli 2000 , op.cit. (n.25).

${ }^{38}$ See Wallace-Hadrill 2001, op.cit. (n. 6), 136-141.
} 
Augustan ideology of pietas is diffused socially, and has drawn particular attention to the altars of the vicomagistri, and the role of cult in creating a channel of communication between the ruler and his people. ${ }^{39}$ Building on that insight, we may observe that the cult goes beyond a two-way communication between ruler and people, in having the effect of incorporating an otherwise marginalised group (ex-slaves being marked above all by rules of exclusion) within the system of imperial order. The essence of civilitas is a social pact of mutual respect. What catches our attention is the inclusion of the Genius Augusti among the Lares and the implicit veneration of the emperor throughout the capital, ward by ward. ${ }^{40}$ But of equal importance is the reciprocal respect afforded to the vicomagistri themselves. Just as much as the imperial cult afforded cities an arena for competition for local respect, ${ }^{41}$ the new system of vici offered the city neighbourhoods, and above all the craftsmen and artisans of low status who provided their backbone, a field of competition within which local distinction could find expression.

The social issues at stake come out in two passages by Augustan authors, Dionysius and Livy, who both seem to be projecting onto the republican past the concerns of the Augustan age (but in the process have caused much confusion and argument). Dionysius describes the compitalia as an institution of Servius Tullius, and appends a revealing social comment:

"And in the rituals they preserve the ancient usage of making offerings to the heroes (i.e. Lares) through slaves, and for those days they eliminate all signs of servitude, to the end that the slaves, reconciled by such a grand and solemn sentiment of humanity, should become more grateful to their patrons and better tolerate the weight of their destiny." (Antiquitates Romanae 4.14.4)

Involvement of slaves in the ritual of the compitalia is seen as a mechanism of binding slaves into the social system. Livy's comment, by contrast, is focus on the degree of social dignity permitted to the vicomagistri. The comment is put in the mouth of a tribune of $195, \mathrm{~L}$. Valerius, contrasting the

\footnotetext{
${ }^{39}$ Zanker 1988, op.cit. (n.17), 129-135.

${ }^{40}$ M. Beard, J. North \& S.R.F. Price, Religions of Rome I: A History (Cambridge 1998), 184-186 underlines the topographical incorporation of the emperor into the fabric of the city - but not of the vicomagistri into the fabric of the state.

${ }^{41}$ S.R.F. Price, Rituals and Power. The Roman imperial cult in Asia Minor (Cambridge 1984).
} 
widespread use of purple as a status symbol for magistrates, priests, children, and local magistrates to the exclusion of women from the use of purple:

\begin{abstract}
"Can we allow the right, here in Rome, to men of the lowest sort, magistri vicorum, of wearing the toga praetexta, and not only to wear this status symbol in life but even to be cremated with it in death, and not allow the use of purple to women?"42
\end{abstract}

Leaving aside all the problems of when these passages were written, in both are clear the assumptions that the men involved in the compitalia or the vici, even the magistrates, were of the lowest status (infimo genere) and that at the heart of the ritual was an appreciation of the respect it allowed them. The symbolical importance of wearing the toga praetexta is similarly highlighted by Dio (55.8.6-7), who adds that the vicomagistri were entitled to the use of two lictors within their zone; and it is already prefigured by Cicero's sharp criticisms of Piso for permitting Sex. Cloelius to celebrate neighbourhood games praetextatus (In Pisonem 8 and 23).

About the fulfilment of this respect, the Augustan and post-Augustan monuments are eloquent. ${ }^{43}$ The scenes depicted on the altars, like that of the Vicus Aesculetius, at once make the tribune Valerius' point: the freedmen vicomagistri in their purple bordered togas, caught in mid ritual like the best of Roman magistrates, glow with local pride. ${ }^{44}$ The reciprocity of the exchange is explicit on scenes like that of the Belvedere altar: in the act of handing his Lares, the Lares Augusti, to the local magistrates, he gives them respect, and demands it back from them. ${ }^{45}$ This same reciprocity is prefigured in Suetonius' account of the precious statues donated by Augustus to individual vici from the New Year's day tips given to him (Augustus 57): what the Roman people give to him, he gives to them. Or take the simple but

\footnotetext{
${ }^{42}$ Livy 34.7.2-3: Purpura viri utemur, praetextati in magistratibus, in sacerdotiis; liberi nostri praetextis purpura togis utentur; magistratibus in coloniis municipiisque, hic Romae infimo genere, magistris vicorum, togae praetextae habendae ius permittemus, nec ut vivi solum habeant tantum insigne sed etiam ut cum eo crementur mortui: feminis dumtaxat purpurae usu interdicemus. On the Augustan stamp of the entire passage, see N. Purcell, 'Livia and the womanhood of Rome', Proceedings of the Cambridge Philological Society 32 (1986), 83f.

${ }^{43}$ For detailed discussion, P. Zanker, 'Über die Werkstätten augusteischer Larenaltäre und damit zusammenhangende Probleme der Interpretation', Bullettino della Commissione Archeologica Comunale di Roma 82 (1970/71), 147-155.

${ }^{44}$ Zanker 1988, op.cit. (n.17), 133, fig.108; G.L. Gregori \& M. Mattei, eds., Supplementa Italica Imagines. Roma (CIL, I) Musei Capitolini (Rome 1999), 32-33, nr. 6.

${ }^{45}$ Zanker 1988, op.cit. (n.17), 133, fig.109; Beard, North \& Price 1998, op.cit. (n. 40), 187, 4.3.
} 
exquisitely elegant carving of the altar of the Vicus Statae Matris. ${ }^{46}$ The symbol of what made Augustus august, the oak wreath for saving the lives of citizens (cives, we note), surrounds the names of four slaves, the ministri of year VI. We should not too easily take for granted the capacity of Roman visual expression not merely to mirror the Roman social hierarchy, but to push its language to the limits, investing the slave with the dignity of the citizen in a reference that goes to the symbolic heart of the Augustan principate.

A more sophisticated example is offered by the long inscription from an anonymous vicus in Testaccio behind the Porticus Aemilia termed the Fasti Magistrorum Vici, and included by Degrassi in his publication of the Fasti. ${ }^{47}$ The inscription is split between the two faces of the same stone. Each side parades in its upper half six months of the calendar and in its lower part one of two lists of magistrates, an arrangement that implies that the two are a mirror image. The first is of the consuls and censors, starting from Augustus' first consulship. The second is the fasti of the magistri of this particular vicus, dating back to their inaugural year, $7 \mathrm{BC}$. The statement that vicomagistri are worthy of fasti just like consuls could hardly be more pointed. But just in case we are lulled into thinking that this inscription served an essentially administrative function, of recording the names of officials responsible year by year, Rüpke has pointed out that the list fell far short of efficiency. ${ }^{48}$ The magistrates of the first 9 years are listed, down to $\mathrm{AD} 2 / 3$. Suddenly the college of $\mathrm{AD} 14$ intervenes; the list returns to 5/6, then back to 18 , then to 21 . It was up to the individual colleges to cover the costs of adding their own names to the monument, and not all were as enthusiastic at this self-promotion as others. By no coincidence, the magistrates of 14 and 21 were the same people, and they enthusiastically filled up any spare gap on the stone.

Possibly something similar is at work on the greatest of all vicus monuments, the honorific altar from the Capitoline dedicated to Hadrian in $\mathrm{AD} 136$ 'by the magistri vicorum of the 14 regions of the city'. ${ }^{49}$ That is what the inscription says, yet what we have is at best a fraction, some 66 of the over 265 vici. But for once it is not because the inscription is fragmentary. It starts,

\footnotetext{
${ }^{46}$ Supplementa Italica Imagines 1999 , op.cit. (n. 44), 30-31, nr.5.

${ }^{47}$ A. Degrassi, Inscriptiones Italiae XIII.1 (1947), 279-290; G. Mancini, 'Fasti consolari e censorii ed elenco di vicomagistri rinvenuti in via Marmorata', Bullettino della Commissione Archeologica Comunale di Roma 63 (1935), 35-79, with Degrassi, ibidem, 173-178.

48 J. Rüpke, 'Les archives des petits collèges. Le cas des Vicomagistri', in La Mémoire perdue. Recherches sur l'administration romaine. Collection de l' École Française de Rome 243 (1998), 27-44.

${ }^{49}$ CIL VI 975 with 31218; ILS 6073; Supplementa Italica Imagines 1999, op.cit. (n.44), 112-115, nr. 169.
} 
on the left side, with 9 vici from Regio I (only a selection), goes on to 6 from Regio X (a smaller selection), then to 17 from Regio XIII (this could be the full list). The right side jumps back to Regio XII, with 12 vici, and finishes with 22 from Regio XIV (making Trastevere easily the best-known region). The back of the monument is blank, which makes it extraordinarily unlikely that the other Regions ever featured. It was seemingly up to each region and vicus to decide whether to finance the extra stone cutting. ${ }^{50}$ The names we see are the result of local pride and the desire for self-advertisement. It may be no coincidence that it is in the peripheral Trastevere that the local magistri show most competitive zeal to memorialize themselves.

My argument that the vici are a system of local social respect is not undermined by this failure. Augustus might like us to have a rosy picture of everyone buying into his system. But there is great latitude for variation, and not everyone cared equally at all periods or in all neighbourhoods. I draw attention to one final bit of evidence, which is the funerary inscriptions of those, typically craftsmen, who state their vicus on their tombstone. Take the Vicus Longus of the Viminal (Regio VI). We have a nice couple, Nostia Daphne the hairdresser and her partner Nerius Quadratus the goldsmith. Then there is Daphne's freedwoman Nostia Cleopatra, a hairdresser too. Finally there is Servilia Aucta from the Vicus Longus by the statue of Plancus (probably Munatius). ${ }^{51}$ But then, what about all the tradesmen who omitted to mention their vicus? I count only 24 individuals from 14 vici who expressed their local affiliation in this way, out of the tens of thousands of funerary inscriptions. ${ }^{52}$ To return to the Vicus Longus, what do we make of Q. Fabius Theogonus the pigmentarius who traded on the Esquiline near the statue of Plancus, who omits the name of the vicus? ${ }^{53}$ It emerges that the vicus was indeed a potential source of local pride and identity to the petty traders of Rome; but that it did not necessarily work for all of them all of the time.

I started by raising the issue of the role of ideal and praxis in the formation of city fabric. What I think emerges from my review of the evidence is that we cannot regard vici as a sort of administrative structure imposed on the urban fabric by the authorities. Vici are deeply rooted in praxis, a grassroots neighbourhood formation which is recruited by Augustus to support his urban order. It follows that what we should expect on the ground is not a sort

\footnotetext{
${ }^{50}$ So Rüpke 1998, op.cit. (n.48), 33-36.

${ }^{51}$ CIL VI 37469 (Nostia Daphne and Nerius Quadratus); 9736 (Nostia Daphnidis 1. Cleopatra); 10023 (Servilia Aucta).

${ }_{52}$ The count is based on the material in LTUR V (above).

${ }^{53}$ CIL VI, 9673.
} 
of ideal order, but the natural agglomeration of activities that arise from the economic life of the city. In the final part of this paper, I want to attempt to restore the vicus to some sort of archaeological visibility. While in Pompeii it is relatively easy to grasp a sense of neighbourhood, ${ }^{54}$ in Rome it is exceptionally difficult, because the archaeology of non-monumental Rome is so badly neglected. I can offer no more than a few fragments.

For a vision of a compital shrine, we are reduced to a single monument, the Compitum Acilii. ${ }^{55}$ Its fragmentary survival is owed to a double destruction. Because of its position at the bottom of a slope near the valley of the Colosseum, it was first demolished by Nero in his post-fire construction of the Domus Aurea (ironically for my argument, our single shrine thus illustrates the lack of imperial respect for a local neighbourhood!); it was then rediscovered during Mussolini's destructive building of the Via dell'Impero. It illustrates the form of aedicula or temple in miniature, which is often referred to in compital inscriptions (the Regionary Catalogues claim one for each vicus). The aedicula stands to the vicomagister as the aedes to the state magistrate.

In association with the aedicula one should look for some sort of assembly hall - the word schola is favoured by modern scholarship - in which the vicus officials could meet, keep their records (album), and surely also feast (not specifically attested). ${ }^{56}$ The Fasti Magistrorum Vici from the Via Marmorata were found in association with one such schola. ${ }^{57}$ Its dimensions are generous enough $(12.10 \times 6.60 \mathrm{~m}$.) to allow substantial gatherings. The niches, I note, would be handy for honorific statues, if any could afford them, or at least for honorific inscriptions.

Both schola and aedicula would be suitable locations for the altars which constitute the typical surviving compital monument. The altar of the Vicus Aesc(u)leti was discovered in 1887 during the construction of the Via Arenula, which slices through the grain of the ancient road pattern. It was

\footnotetext{
${ }^{54}$ For the Pompeian material see the full discussion of W. van Andringa, 'Autels de carrefour, organisation vicinale et rapports de voisinage à Pompéi', Rivista di Studi Pompeiani 11 (2000), 47-86. ${ }^{55}$ Zanker 1988, op.cit. (n.17), 130-132; LTUR I, 314-315 s.v. Compitum Acilium; M. Dondrin-Payre, 'Topographie et propaganda gentilice: le compitum Acilium et l'origine des Acilii Glabriones', in L'Urbs. Espace urbain et histoire (Actes Colloque Rome, 1987), 87-109. On compital shrines, G. Pisani Sartorio, 'Compita Larum: edicole sacre di Roma antica' in Edicole Sacre Romane (1990), 65ff. ${ }^{56}$ LTUR IV, 243-261 collects toponyms identified as Scholae; on the type of structure, see B. Bollmann, Römische Vereinshäuser. Untersuchungen zu den Scholae der römischen Berufs-, Kult-und Augustalen-Kollegien in Italien (Mainz 1998), esp 180-195 on Rome.

${ }^{57}$ LTUR IV, 260-261 s.v. Schola (via Marmorata).
} 
associated with a pavement inscribed by the magistri vici Aescleti anni VIIII. ${ }^{58}$ Thirty years later, the Ministero di Grazia e Giustizia was constructed in the same spot, fragments of two further inscriptions emerged, but were never reported. By a fine piece of detective work, Silvio Panciera has shown that they came from dedications by the magistrates of the first year (i.e. $7 \mathrm{BC}$ ), and by a group under Domitian who undertook restoration. ${ }^{59}$ Because the construction of both the Via Arenula and the Ministry were undertaken with total lack of interest in the ancient urban fabric, we have lost a golden chance to reconstruct the context of these inscriptions.

However, we have only to move a few yards westwards down the same ancient road to meet an exceptional instance of an ancient vicus that is preserved in the modern street pattern. The Vicus [Sta]blarius is one of only three vicus names preserved on the Severan marble plan. ${ }^{60}$ Emilio Rodriguez-Almeida brilliantly demonstrated that the fragments belonged near the Theatre of Pompey, and with a minimum of stretching fitting perfectly into the modern street plan. ${ }^{61}$ Lorenzo Quilici, in the course of excavations near to S. Paolo alla Regola, was able to show that the street plan of the southern Campus Martius preserves extensively that of the imperial period. ${ }^{62}$ If we return to the Vicus Stablarius pattern, we may be struck (as by other fragments of the same plan) by the dense network of shops and small businesses that dominate the urban fabric.

It would be enormously valuable to see a vicus on the ground, not just on a street plan. Rome offers just one exceptional example of something more approaching an urban setting. The exhibition, Antiche Stanze, which 5 years ago meticulously reconstructed the excavations in the Termini area, never published since their demolition in 1948, called the area it reconstructed 'un quartiere di Roma imperiale'.63 'Quartiere' is maybe an overstatement. In antique terms, to reach the level of quartiere or contrada (or the various other local divisions of the medieval city) you would need to look at a regio rather than a vicus; and even for the latter, unless the statistics gravely mislead, you

\footnotetext{
${ }^{58}$ LTUR I, 316 s.v. Compitum vici Aesc(u)leti.

${ }^{59}$ S. Panciera, 'Ancora tra epigrafia e topografia' in L'Urbs 1987, op.cit. (n. 55), 62-73.

${ }^{60}$ LTUR V, 190-191.

${ }^{61}$ E. Rodríguez Almeida, 'Forma Urbis Marmorea: nuove integrazioni', Bullettino della Commissione Archeologica Comunale di Roma 82 (1970/71), 113-115.

${ }^{62}$ L. Quilici, 'Il Campo Marzio occidentale' in Città e architettura. Analecta Romana Instituti Danici suppl. 10 (1983), 59-85.

${ }^{63}$ M. Barbera \& R. Paris, eds., Antiche Stanze. Un quartiere di Roma imperiale nella zona di Termini. Museo Nazionale Romano Terme Diocleziano, Roma dicembre 1996-giugno 1997 (Milan 1996).
} 
would be looking at 5-10 hectares, something more like one of Fiorelli's regiones of Pompeii, composed of a good dozen urban blocks.

This is just a corner of a vicus, but it is enough to reveal something of its cellular structure. I have in other contexts drawn attention to the way it illustrates the mixture of rich and poor, of luxury and commerce. ${ }^{64}$ There is a dominant property, with fairly spectacular decoration, which we may call a domus, though it evidently forms part of an insula. ${ }^{65}$ But attached to the domus is a range of rentable and commercial property. That it is interlinked is emphasised by the network of drains, which connect all 5 blocks, and point to simultaneous construction in the reign of Hadrian, presumably by a single proprietor, possibly a member of the imperial family. ${ }^{66}$ Most conspicuously, there is a balneum, a bath suite that is evidently intended for more than private use by the residents. ${ }^{67}$ There is commercial activity, in a fullery. ${ }^{68}$ There is a good chance of rented cenacula above the domus, for though the curators of the exhibition imagine the upper floor must have been restricted to slaves or family members, the breadth of stairway and the external access would be taken elsewhere as a sure sign of rental space. ${ }^{69}$ Certainly there is rental property in the complex of blocks over the road (C/D). We can see the telltale inner stairways of shop/flat units, and the exterior staircases of cenacula. ${ }^{70}$

My interest in this context is attracted by the North Eastern block (B), which butts against the Servian Agger. This was excavated during the first construction of the station in the 1860s, and the records and details are unclear. What is evident is that the lower floor is built around a single room of exception size, and also, as Parker's photograph reveals, of exceptional height. This has been interpreted as an unusually luxurious private apartment. ${ }^{71}$ That seems to me implausible, and I would rather see in it a large space for some sort of communal activity along the lines of a schola or collegium. A parallel

\footnotetext{
${ }^{64}$ See A. Wallace-Hadrill, 'Domus and Insulae in Rome: Families and Housefuls', in D.L. Balch \& C. Osiek, eds., Early Christian Families in Context: An Interdisciplinary Dialogue (Ann Arbor, forthcoming 2003), ch.1.

${ }_{65}^{65}$ E1-11, 13-16, 19-20, 31: Barbera \& Paris 1996, op.cit. (n. 63), 71-115.

${ }^{66}$ Barbera \& Paris 1996, op.cit. (n. 63), 179-189

${ }^{67}$ E12, 17-18, 24-30, 30, 32-34, 36: Barbera \& Paris 1996, op.cit. (n. 63), 117-167.

${ }^{68}$ E21: Barbera \& Paris 1996, op.cit. (n. 63), 170-171.

${ }^{69}$ Barbera \& Paris 1996, op.cit. (n. 63), 71; contrast F. Pirson, Mietwohnungen in Pompeji und Herkulaneum. Untersuchungen zur Architektur, zum Wohnen and zur Sozial- und Wirtschaftsgeschichte der Vesuvstädte (Munich 1999), esp. 75ff. on the implication of external stairs.

${ }^{70}$ External stairs are visible in plan at $\mathrm{C} 2$ and D1; internal stairs at C5, D2-5.

${ }^{71}$ Barbera \& Paris 1996, op.cit. (n. 63), 185-187.
} 
could be the collegium of the Augustales at Herculaneum. ${ }^{72}$ This is both a shrine and a meeting place, surely used for feasting; and it is the place where the lists of the Augustales were displayed. It seems to me that there is a close parallel between the local pride evinced by the Augustales of a small town, and that of the magistri of a vicus in Rome.

What I see here is a rhythm of interconnected private spaces (residences and shops), and common spaces (the balneum, and my suggested schola/collegium), as of residential and commercial. How does imperial power 'inscribe itself' on this complex? Not, we note, by rectilinear planning: the angle introduced by the long bend of the Servian wall generates an angle of 30 degrees, which is skilfully accommodated by the architect in the ship-like prow in which the domus nestles. Yet there is a good possibility that the investors were members of the imperial family itself. Imperial order is visible in the high quality brick and concrete construction of all these units, in the interconnectedness of the drains, the healthy obsession with bathing, replicated so many times across the city; but also I suggest in a sense of ordered local neighbourhood with focal points of social interaction, local dignity, and respect for the system.

My argument, then, is that the way imperial power inscribes itself in the ordinary urban fabric of the city is not so much about creating an 'ideal city' of well-ordered grid patterns and straight avenues with vistas, but rather about penetrating the socio-urban fabric, of acknowledging the potentially dangerous clusters of local neighbourhoods and the 'low-life' they represent, and by a social pact of offering respect recruiting them to a collusion in the process of ordering the city. Emperors favoured grid plans, of course, and when they had the chance like Nero constructed broad avenues with buildings following strict regulations. But we never hear of them embarking on programs of slum clearance, like Mussolini or twentieth-century town planners. Respectful of property rights, they embraced local communities to avoid alienation and recruit support for the system. It is, I suggest, in concern for urban order at this micro-level, as much as in the macro-level of the seating system of the Colosseum, that Roman imperial power displays its chosen colours.

Rome, July 2003.

72 G. Guadagno, 'Herculanensium Augustalium aedes', Cronache Ercolanesi 13 (1983), 159-173; Bollmann 1998, op.cit. (n. 56), 348-354. 